\title{
廃棄樹皮から水熱抽出して得られた縮合型タンニンのマトリックス 支援レーザー脱離イオン化質量分析法による構造解析
}

\author{
牧 瑛 ${ }^{1}$, 荻本健一郎 ${ }^{1}$, 石田 康行 $^{\circledR 1}$, 大 谷 肇 $^{2}$, 長谷川達也 ${ }^{3}$, \\ 北川 邦行 $^{3}$, 本馬 洋子 ${ }^{4}$, 稲井 淳文 $^{4}$
}

\section{1 緒言}

縮合型タンニンは, コナラやアカシア属などの樹木の, 主に樹皮部分に含まれる水溶性ポリフェノール化合物の一 種である. Fig. 1 にその構造を示すように, 縮合型タンニ ンは, フラバン-3-オール単位を基本骨格とする, 平均分子 量が数百から数千の重合体である ${ }^{1)}$.このタンニン主鎖を 構成するフラバン-3-オール単位には，当該分子中に含まれ るヒドロキシル基の数が異なる, 複数の種類が存在する. このように，縮合型タンニンは，様々な分子量やモノマー 組成をもつ成分からなる複雑な混合系である。この夕ンニ ン成分は，従来，皮のなめし剂として広く用いられてきた が, 現在は木材用接着剤や凝集剤としても実用化されてい る. 更に, 抗酸化性や抗菌性などの様々な生理活性を有す るため ${ }^{2)}$, 最近では医薬品としての利用が期待されている.

この縮合型タンニンなどの有価物質を多く含む木材の樹 皮部分は, 現在, 日本の製材工場から年間約 350 万 $\mathrm{m}^{3}$ も 排出されている 皮中に含まれる縮合型タンニン成分を効率よく抽出し，そ れらを有効利用することが，バイオマス活用の観点から求 められている. 一般に, 木材からの縮合型タンニンの回収 には，メタノールやアセトンなどを用いた有機溶媒抽出法 が用いられている。 しかしながら，この方法では，有機溶 媒を使うために環境への負荷が大きいことから，よりクリ ーンな抽出方法の採用が望まれている.

こうした中で，近年，亜臨界水を媒体に利用した水熱プ ロセスが，比較的短時間で効率よく抽出を行える低環境負 荷型の方法として注目されている。 これまでに，この水熱 抽出を用いて, 様々なバイオマスから生理活性物質 ${ }^{4) 5}$ や機 能性食品成分 ${ }^{6}$ などの生理活性物質を回収した研究例が報

\footnotetext{
${ }^{1}$ 中部大学応用生物学部応用生物化学科 : 487-8501 愛知県春日 井市松本町 1200

2 名古屋工業大学工学研究科物質工学専攻 : 466-8555 愛知県名 古屋市昭和区御器所町

3 名古屋大学エコトピア科学研究所 : 464-8603 愛知県名古屋市 千種区不老町

${ }^{4}$ 株式会社コシイウッドソリューションズ : 559-0026 大阪府大 阪市住之江区平林北 1-2-158
}

告されている．更に，著者らは，水熱プロセスによりアカ シア属 (Acacia mangium) の廃裹樹皮から縮合型タンニン を迅速かつ高効率に抽出する試みを検討してきた7゙.

この水熱法によって得られる縮合型タンニンの分子構造 は，温度や圧力などの抽出プロセスに関する諸条件の違い によって, 大きく変化することが予想される. したがって, 水熱抽出条件の高効率化を図るためには, 様々な条件下で 抽出したタンニン成分の詳細な構造解析を実施し，その結 果を考慮して水熱条件の適正化を行うことが重要である. 一般に，タンニン類の分析には，液体クロマトグラフィー $(\mathrm{LC})^{8) 9}$ や核磁気共鳴法 (NMR $)^{10111}$ などの手法が用いられ てきた．しかしながら，前者の方法では，主に低分子量成 分しか測定対象になり得ないこと，また後者では，測定に 先立って精製などの煩雑な試料前処理操作が必要であるこ とがそれぞれ問題点として指摘されている，そのため，い ずれの方法も, 多様な抽出条件下で得られた, 数多くの夕 ンニン試料のスクリーニングに求められるような，迅速性 や簡便性などの諸条件を必ずしも満たすものではない．

これに対して, 最近, 飛行時間型質量分析計を用いるマ トリックス支援レーザー脱離イオン化質量分析（MALDIMS）が, 多検体を一度に扱い，煩雑な試料前処理操作を一 切行わずに縮合型タンニンの分子構造を解析できる手法と して利用されている。これまでに，この方法により縮合型

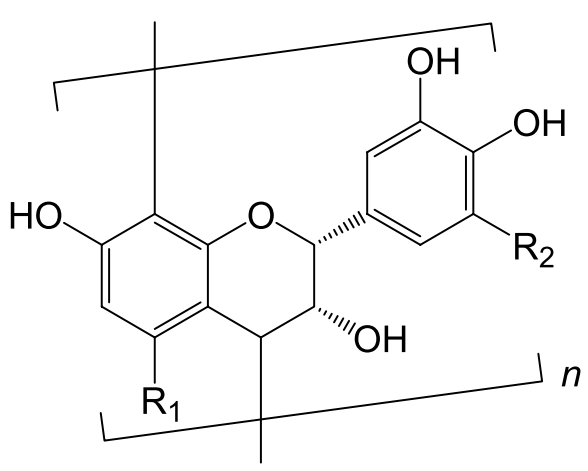

Fig. 1 Possible structure of condensed tannin $R_{1}, R_{2}=\mathrm{H}$ or $\mathrm{OH}$ 
タンニンの分子量や化学構造の解析などを行った例が報告 されてきた ${ }^{11) \sim 15)}$. 例えば, Pasch らは, 縮合型タンニンを MALDI-MS 測定して得られた質量スペクトルから当該成 分の数平均分子量を算出し，その值が NMR によるデータ とよく対応することを報告した ${ }^{12)}$. また, 著者らの研究グ ループは, 固体試料調製法を採り入れた MALDI-MS によ り,アカシア属の樹皮中に含有される縮合型タンニンの分 析を, 粉末状の木材試料をそのまま測定に供して迅速に行 えることを報告した ${ }^{13)}$.

そこで, 本研究では, 廃裹樹皮から水熱抽出した縮合型 タンニンの MALDI-MS 測定を通じて, 水熱抽出条件とタン ニン成分の分子構造間の関係を精査することを目的とし た. ここでは, 水熱法に関するパラメー夕類のうち, 温度 に注目し, 抽出温度を変えて回収したタンニン分子の重合 度やモノマー構造を MALDI-MS により解析することを試 みた。こうして得られた，タンニン成分の分子構造に関す る知見を基に, 廃棄樹皮からのタンニン抽出における水熱 温度の適正化を行うことを目指した，更に，タンニン成分 の抗酸化性試験を実施し, 当該成分の抗酸化性能をその重 合度と関連付けて考察することも目的とした。

$$
2 \text { 実験 }
$$

\section{$2 \cdot 1$ 試 料}

試料には, 縮合型タンニンを比較的多く含むことが知ら れているアカシア属 (Acacia mangium) の樹皮を用いた.こ の樹皮試料を凍結粉砕して, 微細粉末状にしたもの（粒径 はおよそ $0.1 \mathrm{~mm}$ ）を水熱抽出に供した.

\section{$2 \cdot 2$ 樹皮試料からの縮合型タンニンの抽出}

水熱抽出では, まずステンレス製の反応管（SUS316 製, 長さ $12 \mathrm{~cm}$, 内容量 $10 \mathrm{~mL}$ ) の中に, 粉砕した樹皮試料 200 $\mathrm{mg}$ と蒸留水 $6 \mathrm{~mL}$ を加えて密栓した後, このステンレス管 を $100 \sim 200^{\circ} \mathrm{C}$ までの任意の温度に保持したオーブン内で 30 分間加熱した. その後, ステンレス管を水道水で満たし たボール中に水浴し, 内容物を室温付近まで泠却した。 引 き続き, ステンレス管から内容物を取り出し, 残存する樹 皮試料を沪紙（Qualitative No.1, Whatman 製）で沪別した 後, 得られた抽出液を真空乾燥器 (CVE-3100, 東京理化器 械製）により乾燥して，固体状の抽出物を回収した。こう して得られた抽出物試料を, 精製などの試料前処理を行わ ず，直接 MALDI-MS 測定に供した。

また，樹皮試料中の夕ンニン成分について参照データを 得るために, 上述した樹皮試料から有機溶媒抽出して得ら れたタンニン成分も実験に使用した。ここでは, 樹皮試料 をメタノール中によく懸濁させた後, この懸濁液を $30^{\circ} \mathrm{C}$ で 30 分間擋拌することにより, タンニン成分の抽出を行 った. その後, メタノールを蒸発させ, 抽出物試料を乾固
させた後, 水熱抽出物の場合と同様にそのまま MALDI-MS 測定に使用した。

なお, 水熱抽出及び有機溶媒抽出のいずれの場合も, 次 式に従って求めた, 抽出物の抽出率は約 $20 \mathrm{wt} \%$ であった.

抽出率 $(\mathrm{wt} \%)=$ 抽出物の乾燥重量 $(\mathrm{mg}) /$ 抽出に供した 樹皮試料の重量 $(\mathrm{mg}) \times 100$

\section{$2 \cdot 3$ 抽出物試料の MALDI-MS 測定}

MALDI におけるマトリックス試薬及びイオン化助剂に は，これまでにタンニン成分のイオン化が高効率に行われ ることが報告されている2,5-ジヒドロキシ安息香酸 $(2,5-\mathrm{DHB})^{11) \sim 13)}$ 及びセシウム塩 ${ }^{11}{ }^{14)}$ をそれぞれ用いた。ま ず，樹皮試料の抽出物 $\left(6 \mathrm{mg} \mathrm{mL} \mathrm{mL}^{-1}\right)$, マトリックス試薬 $\left(30 \mathrm{mg} \mathrm{mL}^{-1}\right)$ 及びョウ化セシウム $\left(1 \mathrm{mg} \mathrm{mL}^{-1}\right)$ のメ夕 ノール/水 $(1: 1)$ 混合溶液を調製した。次に, この溶液の $1 \mu \mathrm{L}$ をステンレス鋼製の試料プレート上に滴下し, 風乾し て MALDI-MS 測定用の試料を調製した.

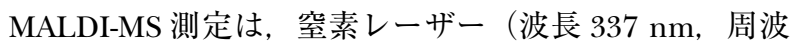
数 $5 \mathrm{~Hz}$ ，パルス幅 $10 \mu \mathrm{s}$ ）及び遅延引き出し機構を有する イオン化源を備えた, 飛行時間型質量分析計（Autoflex, Bluker 製) を用いて行った. 生成したイオンは, 加速電圧 $20 \mathrm{kV}$ に印加されたフライトチューブ内に導入され，リニ アモードで質量分離した後, 検出した. なお, 遅延引き出 し時間は $50 \mathrm{~ns}$ に設定し, 100 回のレーザー照射による各々 の測定結果を積算して一つの質量スペクトルを得た.

\section{$2 \cdot 4$ 抽出物試料の抗酸化性試験}

抗酸化性試験には, Lamaison $5^{16)}$ の報告に従って, 安定 ラジカルである2,2-ジフェニル-1-ピクリルヒドラジル （DPPH）を用いる方法を採用した。 まず，DPPH メタノー ル溶液 $\left(0.04 \mathrm{mg} \mathrm{mL}^{-1}\right) 3 \mathrm{~mL}$ に, 様々な濃度 $(0.008 \sim 1$ $\left.\mathrm{mg} \mathrm{mL}^{-1}\right)$ で調製した，樹皮試料からの抽出物メ夕ノール 溶液 $500 \mu \mathrm{L}$ を加えた. 20 分経過した後に, 残存する DPPH を波長 $517 \mathrm{~nm}$ において紫外・可視吸光光度計（V-550, 日 本分光製）により測定し, 得られた吸光度から次式に従っ て, ラジカル失活率を算出した。

ラジカル失活率 $=($ 空試験の吸光度 - 測定試料の吸光 度) /空試験の吸光度

[空試験 : $0.04 \mathrm{mg} \mathrm{mL}^{-1}$ メタノール溶液]

また，抗酸化性能の参照值を得るために，現在，抗酸化 凨として広く利用されている $\alpha$-トコフェロール (ビタミン $\mathrm{E}$ ) を試料に用い, 上述の方法に従って, そのラジカル失活率 を求めた. なお, 抗酸化性の評価は $50 \%$ 有効濃度（Effect 


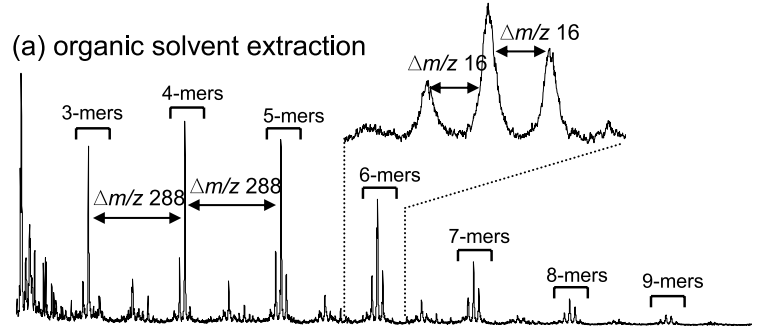

(b) $200^{\circ} \mathrm{C}$

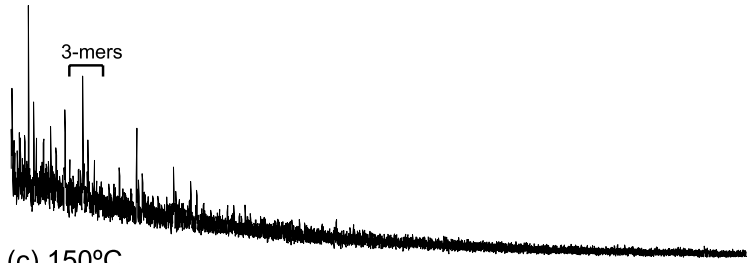

(c) $150^{\circ} \mathrm{C}$

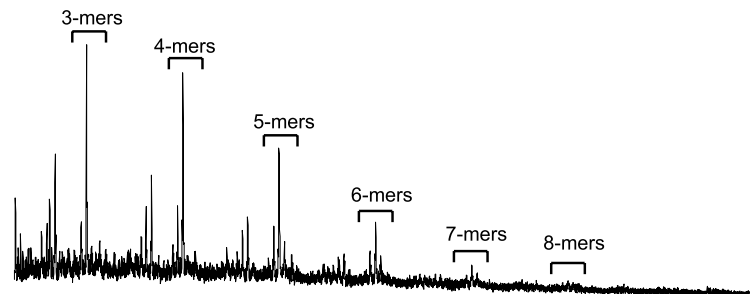

(d) $100^{\circ} \mathrm{C}$

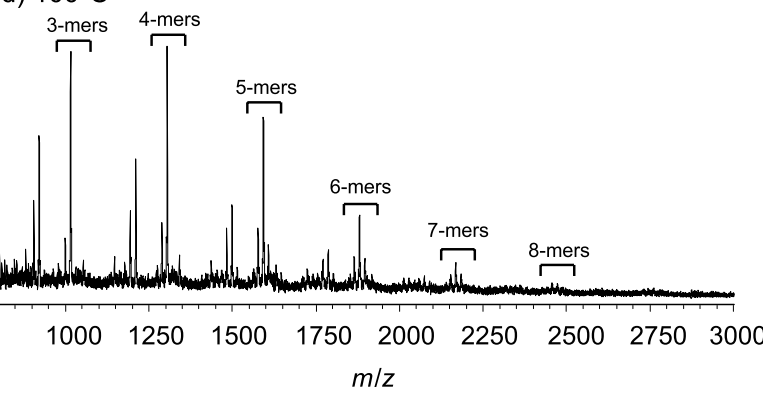

Fig. 2 MALDI mass spectra of tannin components in (a) organic solvent extracts and hydrothermal extracts obtained at (b) $200^{\circ} \mathrm{C}$, (c) $150^{\circ} \mathrm{C}$ and (d) $100^{\circ} \mathrm{C}$

concentration $50 \% ; \mathrm{EC}_{50}$ ）の值を基に行った。この值は, ラジカル失活率が 0.5 を示す試料溶液の濃度のことであ り，その值が低いほど当該試料の抗酸化性能はより優れて いることになる.

\section{3 結果と考察}

Fig. 2 に，(a) 有機溶媒抽出物と,（b） $200^{\circ} \mathrm{C}$ ，(c) $150^{\circ} \mathrm{C}$ 及び (d) $100^{\circ} \mathrm{C}$ において得られた水熱抽出物の MALDI 質 量スペクトルを示す。まず，（a）の有機溶媒抽出物を用い て得られた質量スペクトル上には，質量電荷比 $(m / z)$ が 約 3000 までの一連のピーク群が明瞭に観測された。この スペクトルに示すように，各々のグループのうち，最も強 度の強いピークは $m / z 288$ おきに検出されており, この間 隔は分子中にヒドロキシル基を 5 個含有するフラバン-3-オ ール単位の質量に相当した。更に, 図中の拡大図に示すよ うに, 各グループを構成するイオンピークはそれぞれ $m / z 16$
の間隔をもって観測された.これらの結果と各イオンの $m / z$ の值を総合して，一連のピーク群は，以前に報告され たように ${ }^{11) 14)}$, 含有されるヒドロキシル基数が異なる, 複 数のフラバン-3-オール単位の組合せからなる縮合型タンニ ンのセシウムイオン付加分子であると帅属した。一方, （b）のスペクトル上には，縮合型タンニンに由来するピー クとして，3 量体のイオンがわずかに見られたが，それ以 上の $m / z$ 值を有する重合体はほとんど検出されなかった. このことから, $200^{\circ} \mathrm{C}$ での水熱抽出では, 熱によるタンニ ン成分の分解又は重合反応が著しく進行していることが示 唆された.これに対して，(c) の $150^{\circ} \mathrm{C}$ と（d）の $100^{\circ} \mathrm{C}$ で 得られた抽出物のスペクトル上には，いずれの場合にも重 合度が 8 程度 $(m / z \approx 2500)$ までのタンニン成分に由来す るピーク群がはっきりと観測された。 この結果から, それ らの比較的, 温和な条件 $\left(150^{\circ} \mathrm{C}\right.$ 及び $\left.100^{\circ} \mathrm{C}\right)$ 下での水熱 抽出では, 分解や重合反応などの関与をかなりの程度回避 して，オリゴマー構造を維持したタンニン成分を迅速かつ 高効率にクリーン抽出できることが分かった.

そこで, それらの温度に注目して, 抽出されたタンニン オリゴマーを構成するモノマー成分の解析を試みた。例と して，(c) の $150^{\circ} \mathrm{C}$ で得られた抽出物試料のスペクトルに おける, 3〜 5量体までのオリゴマー領域の拡大図を Fig. 3 に示す。この図では, 溶媒抽出物の場合と同様に, $m / z 288$ おきに主ピークをもつ縮合型タンニンのイオン群が，各々 $m / z 16$ 間隔で見られるサテライトピークを伴って明瞭に 観測された. 同様に，(d）のスペクトル上にも，ほぼ同じ $m / z$ 值を有する，一連のイオンピークが認められた。これ らのイオンのうち, 主なピークについて観測された $m / z$ 值 と, 次式に従って, 3 種類のフラバン-3-オール単位の質量 を考慮して算出した式量を Table 1 にまとめて示す.

$$
\begin{aligned}
m / z \text { of }\left[\mathrm{M}+\mathrm{Cs}^{+}\right] & =132.9(\mathrm{Cs})+18.0(\text { end groups }= \\
& \mathrm{H}+\mathrm{OH})+\left(272.3 \times n_{4 \mathrm{OH}}\right)+(288.3 \times \\
& \left.n_{5 \mathrm{OH}}\right)+\left(304.3 \times n_{6 \mathrm{OH}}\right)
\end{aligned}
$$

ここで, $n_{4 \mathrm{OH}}, n_{5 \mathrm{OH}}$, 及び $n_{6 \mathrm{OH}}$ は, それぞれ対応する数 のヒドロキシル基をもつフラバン-3-オール単位の質量であ る. 更に, ここでは各イオンについて計算した式量を満た す, 3 種類のフラバン-3-オール単位の可能な組合せも併せ て示した（但し，5量体については典型的な組合せ例のみ 記した)。この表に示すように, 水熱抽出物中に含まれる夕 ンニン成分は，ヒドロキシル基を 5 個有するフラバン-3-オ ール単位を主成分として，3 種類の基本単位から構成され ることが分かった。

最後に，質量スペクトル上に観測されるピーク群の $\mathrm{m} / \mathrm{z}$ 值とそれらの面積から，次式に従って，各抽出物中に含ま れる縮合型タンニンの数平均分子量を算出した. 


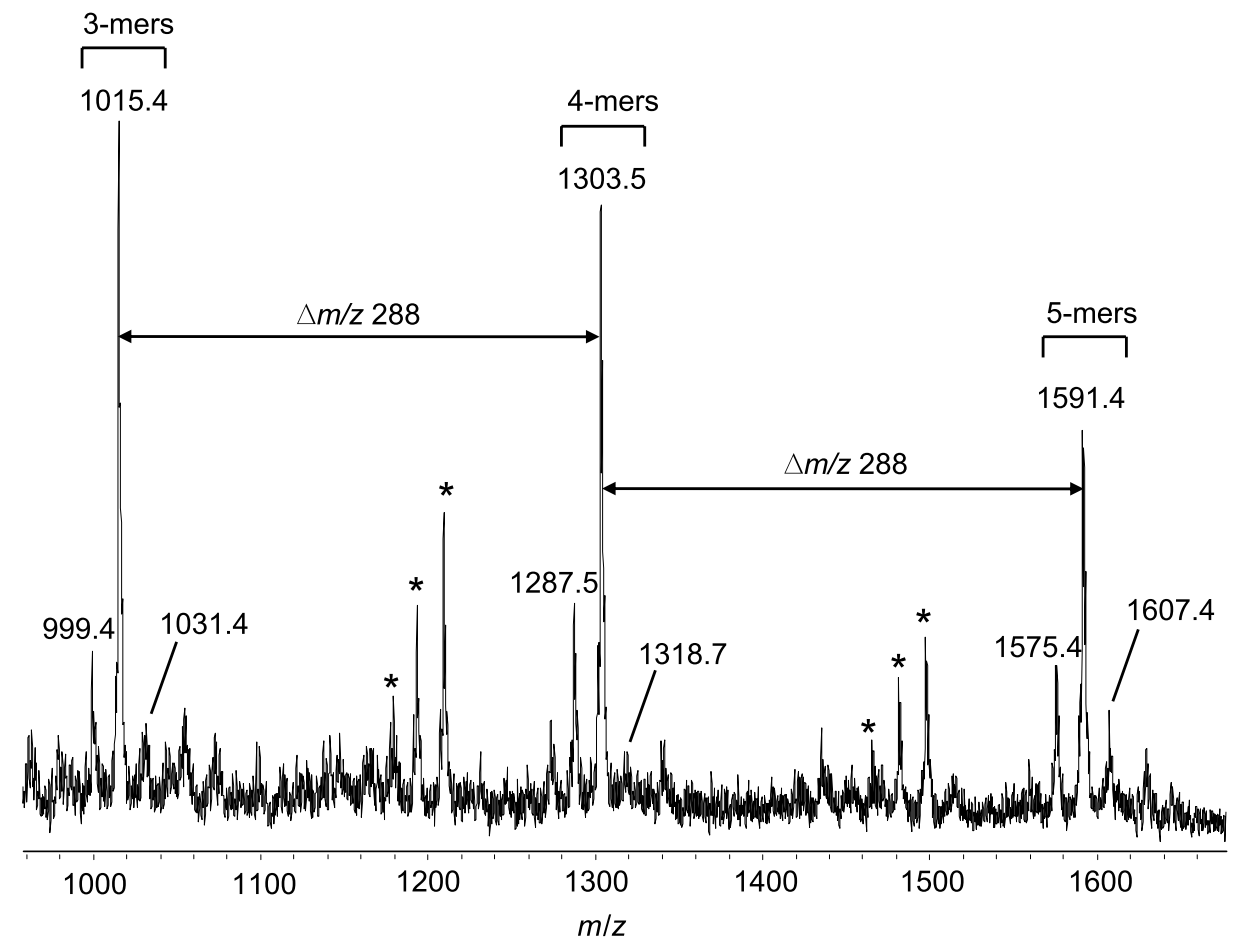

Fig. 3 Expanded MALDI mass spectrum from Fig. 3 (c) in the range $m / z$ 960-1680

* These peaks might be sodiated adducts of condensed tannins.

Table 1 Calculated molar masses for the assigned structures and observed peak top $m / z$ values of tannin components

\begin{tabular}{|c|c|c|c|c|}
\hline \multirow{2}{*}{$\begin{array}{l}\text { Observed } m / z \\
\text { value }\end{array}$} & \multirow{2}{*}{$\begin{array}{c}\text { Calculated molar } \\
\operatorname{mass}^{\text {a) }}\end{array}$} & \multicolumn{3}{|c|}{ Unit type } \\
\hline & & $4 \mathrm{OH}-$ & $5 \mathrm{OH}-$ & $6 \mathrm{OH}-$ \\
\hline \multicolumn{5}{|l|}{ Trimers } \\
\hline \multirow[t]{2}{*}{999.4} & 999.8 & 1 & 2 & - \\
\hline & & 2 & - & 1 \\
\hline \multirow[t]{2}{*}{$1015.3^{\mathrm{b})}$} & 1015.8 & - & 3 & - \\
\hline & & 1 & 1 & 1 \\
\hline \multirow[t]{2}{*}{1031.4} & 1031.8 & - & 2 & 1 \\
\hline & & 1 & - & 2 \\
\hline \multicolumn{5}{|l|}{ Tetramers } \\
\hline \multirow[t]{2}{*}{1287.5} & 1288.1 & 1 & 3 & - \\
\hline & & 2 & 1 & 1 \\
\hline \multirow[t]{3}{*}{$1303.5^{\text {b) }}$} & 1304.1 & - & 4 & - \\
\hline & & 1 & 2 & 1 \\
\hline & & 2 & - & 2 \\
\hline \multirow[t]{2}{*}{1318.7} & 1320.1 & - & 3 & 1 \\
\hline & & 1 & 1 & 2 \\
\hline \multicolumn{5}{|l|}{ Pentamers $^{c)}$} \\
\hline 1575.4 & 1576.4 & 1 & 4 & - \\
\hline $1591.4^{\mathrm{b})}$ & 1592.4 & - & 5 & - \\
\hline 1607.4 & 1608.4 & - & 4 & 1 \\
\hline
\end{tabular}

a) Calculated as cesium ions containing a number of each unit. b) Dominant oligomer. c) A typical example is shown for number of unit in pentamers. 
Table 2 Calculated number-averaged molar masses and $\mathrm{EC}_{50}$ values of extracted tannin components

\begin{tabular}{lccccc}
\hline & \multicolumn{3}{c}{ Hydrothermal extracts } & Organic solvent \\
\cline { 2 - 4 } & $100^{\circ} \mathrm{C}$ & $150^{\circ} \mathrm{C}$ & $200^{\circ} \mathrm{C}$ & $\begin{array}{c}\alpha \text {-Tocopherol } \\
\text { (vitamin E) }\end{array}$ \\
\hline Number-averaged molar mass ${ }^{\mathrm{a})}$ & 1370 & 1430 & 1020 & $\begin{array}{c}1770 \\
(6.8)^{\mathrm{c}}\end{array}$ & - \\
$\mathrm{EC}_{50}\left(\mathrm{mg} \mathrm{mL}^{-1}\right)^{\mathrm{b})}$ & 0.043 & 0.046 & 0.098 & $\begin{array}{l}0.025 \\
(2.4)^{\mathrm{c}}\end{array}$ & 0.058 \\
\hline
\end{tabular}

a) Calculated on the basis of MALDI mass spectra. b) Determined by DPPH method. c) Values in parentheses are relative standard deviations $\left(n=5\right.$ and 3 for molar mass and $\mathrm{EC}_{50}$, respectively)

$$
M_{\mathrm{n}}=\Sigma N_{\mathrm{i}} M_{\mathrm{i}} / \Sigma N_{\mathrm{i}}
$$

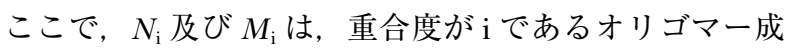
分のそれぞれピーク面積及び質量である。こうして得られ た, タンニン成分の数平均分子量の計算值を, 各抽出物試料 を抗酸化性試験に供して得られた $\mathrm{EC}_{50}$ の值と共に Table 2

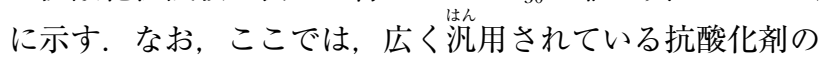
一種である， $\alpha$-トコフェロール（ビタミン E）についての $\mathrm{EC}_{50}$ も参照值として示した. この表において, まず, $200^{\circ} \mathrm{C}$ での水熱抽出物中に含まれる縮合型タンニンの数平均分子 量 $\left(M_{\mathrm{n}}=1020\right)$ は，上述した分解や重合反応の関与のた めに, 溶媒抽出の場合 $\left(M_{\mathrm{n}}=1770\right)$ よりかなり小さい值

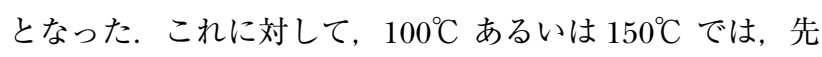
に述べたように，もとのタンニン分子のオリゴマー構造が かなりの程度維持されたことを反映して, 当該成分の数平 均分子量は約 1400 と比較的高い值を示した. また, 数平 均分子量と $\mathrm{EC}_{50}$ 值の関係に注目すると, 含有される縮合型 タンニンの分子量が最大である溶媒抽出物は, 一連の抽出 物の中で最も低い $\mathrm{EC}_{50}$ 值 $\left(0.025 \mathrm{mg} \mathrm{mL}^{-1}\right)$ を示しており, タンニン成分の分子量が大きいと, その抗酸化性能は高く なる傾向が示唆された。 これらの試料のうち, $100^{\circ} \mathrm{C}$ 及び $150^{\circ} \mathrm{C}$ での水熱抽出物の $\mathrm{EC}_{50}\left(0.043 \mathrm{mg} \mathrm{mL}{ }^{-1}\right.$ 及び 0.046 $\left.\mathrm{mg} \mathrm{mL}^{-1}\right)$ は, 溶媒抽出物の值より若干高いものの, 一般 に抗酸化剤として利用されているトコフェロールのデータ $\left(0.058 \mathrm{mg} \mathrm{mL}^{-1}\right)$ より，かなり低い值を示した．このこと から, それらの温度下で水熱抽出して得られたタンニン成 分は, もとの重合体構造をよく保持していることと関係し て, 実用化に十分な抗酸化性能を有することが明らかとな った.

$$
4 \text { まと め }
$$

2,5-ジヒドロキシ安息香酸をマトリックス試薬に用いた MALDI-MS 測定により，アカシア属（Acacia mangium）の 廃棄樹皮の水熱抽出物中には, 主に 3 種類のフラバン-3-オ ール単位から構成される縮合型タンニンのオリゴマーが含 有されていることが分かった，更に，温度を変えて得られ た抽出物の MALDI-MS 測定を通じて, $100^{\circ} \mathrm{C}$ 及び $150^{\circ} \mathrm{C}$ と
いった比較的温和な条件下での水熱抽出では, 高分子量の タンニン成分 $\left(M_{\mathrm{n}} \approx 1400\right)$ を，その分解や重合反応をほ ぼ回避して迅速にクリーン回収できることが分かった．更 に, 水熱抽出物の抗酸化性は, 含有されるタンニン成分の 数平均分子量と密接に関係して㧍り, 上記の温度下で得ら れるオリゴマー構造を保持したタンニン成分は $\alpha$-トコフェ ロールより優れた抗酸化性能をもつことが明らかになっ た. 今後, 主に MALDI-MS を活用し, 温度以外の様々な水 熱パラメー夕の適正化を進めることにより, 工業品や食品 用の抗酸化剂として実際に利用できるタンニン成分を廃裹 樹皮から高効率にクリーン回収できることが期待される.

本研究の一部は, 科学技術振興調整費アジア科学技術協力の戦 略的推進「バイオウエイストのリファイナリー型資源化」, 日本 学術振興会科学研究費補助金基盤研究 (C) (19550085), 名古屋 大学エコトピア科学研究所共同研究費及び中部大学特別研究費 $\mathrm{A}$ （19IIS05A）の援助を受けた.

\section{文献}

1) A. Pizzi, A. Stephanou : J. Appl. Polym. Sci., 51, 2109 (1994).

2) C. Santos-Buelga, A. Scalbert: J. Sci. Food Agric., 80, 1094 (2000).

3) 大原誠資: “樹皮タンニンの多彩な機能と有効利 用”, 第 1 版, p. 3 (2005), (八十一出版).

4) M. Garcia-Marino, J. C. Rivas-Gonzalo, E. Ibáňez, C. Garcia-Moreno : Anal. Chim. Acta, 563, 44 (2006).

5) K. Furukawa, O. Pourali, F. S. Asghari, H. Yoshida : Proceeding of The 3rd International Symposium on Material Cycling Engineering, p. 59 (2008).

6) I. Rodríguez-Meizoso, F. R. Marin, M. Herrero, F. J. Seňorans, G. Reglero, A. Cifuentes, E. Ibáňez : J. Pharm. Biomed. Anal., 41, 1560 (2006).

7) Y. Ishida, Y. Nakamura, T. Nagaoka, K. Kitagawa, T. Hasegawa : Proceeding of International Symposium on EcoTopia Science 2007, p. 593 (2007).

8) J. A. Kennedy, A. L. Waterhouse : J. Chromatogr. A., 866, 25 (2000).

9) Z. Peng, Y. Hayasaka, P. G. Iland, M. Sefton, P. Hoj, E. J. Waters : J. Agric. Food Chem., 49, 26 (2001).

10) Z. Yu, R. A. Dahlgren : J. Chem. Ecol., 26, 2119 (2000).

11) L. Zhang, Y. Lin : Molecules, 13, 2986 (2008).

12) H. Pasch, A. Pizzi, K. Rode : Polymer, 42, 7531 (2001).

13) Y. Ishida, K. Kitagawa, K. Goto, H. Ohtani : Rapid Commun. Mass Spectom., 19, 706 (2005). 
14) M. Ohnishi-Kameyama, A. Yanagida, T. Kanda, T. Nagata: Rapid Commun. Mass Spectom., 11, 31 (1997).

15) C. Mané, N. Sommerer, T. Yalcin, V. Cheynier, R. B.
Cole, H. Fulcrand : Anal. Chem., 79, 2239 (2007).

16) J. L. Lamaison, C. Petitjean-Freyret, A. P. Carnat, A. Carnat: Plantes. Med. Phytother., 22, 231 (1988).

\title{
Structural Analysis of Condensed Tannins in Hydrothermal Extracts from Wasted Bark by Matrix-Assisted Laser Desorption/ Ionization Mass Spectrometry
}

\author{
Akira Maki $^{1}$, Kenichiro OgImoto ${ }^{1}$, Yasuyuki Ishida $^{1}$, Hajime Ohtani ${ }^{2}$, Tatsuya Hasegawa ${ }^{3}$, \\ Kuniyuki KitAGAwA ${ }^{3}$, Yoko Homma ${ }^{4}$ and Atsunori INAI ${ }^{4}$
}

${ }^{1}$ Department of Biological Chemistry, College of Bioscience and Biotechnology, Chubu University, 1200 , Matsumoto-cho, Kasugai-shi, Aichi 487-8501

${ }^{2}$ Department of Materials Science and Engineering, Graduate School of Engineering, Nagoya Institute of Technology, Gokiso-cho, Showa-ku, Nagoya-shi, Aichi 466-8555

${ }^{3}$ EcoTopia Science Institute, Nagoya University, Furo-cho, Chikusa-ku, Nagoya-shi, Aichi 464-8603

${ }^{4}$ Koshii Wood Solutions Co., Ltd., 1-2-158, Hirabayashi-Kita, Suminoe-ku, Osaka-shi, Osaka 559-0026

(Received 14 March 2009, Accepted 23 June 2009)

Matrix-assisted laser desorption/ionization mass spectrometry (MALDI-MS) was applied to a structural analysis of condensed tannins extracted from wasted bark through a hydrothermal process under different temperatures. The mass spectra of hydrothermal extracts obtained at $100^{\circ} \mathrm{C}$ and $150^{\circ} \mathrm{C}$ showed a series of peaks for the tannin oligomers up to 8-mers, consisting mainly of the combination of three types of flavan-3-ol units. This result suggests that hydrothermal extraction under these temperatures leads to a rapid recovery of the tannin components while keeping their oligomer structure. On the other hand, the ion peak of the tannin oligomer was almost missing from the mass spectrum of extracts obtained at $200^{\circ} \mathrm{C}$, suggesting that degradation and/or polymerization of the tannins occurred significantly through the extraction procedure under this temperature. Furthermore, the number-averaged molar masses of the tannin components in each extract sample were calculated on the basis of their corresponding mass spectra, and interpreted in terms of the antioxidant activity. This interpretation revealed that 1) the antioxidant activities for the tannin components increased with an increase in their number-averaged molar masses, and 2) the tannin components in hydrothermal extracts obtained under lower temperatures showed relatively higher antioxidant activities than $\alpha$-tocopherol.

Keywords : hydrothermal extraction ; condensed tannins ; matrix-assisted laser desorption/ionization mass spectrometry ; wasted bark ; antioxidant activity. 